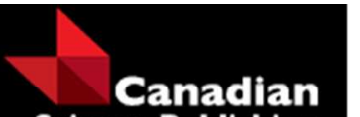

\title{
Historical avenues of research in Russian forest typology: ecological, phytocoenotic, genetic, and dynamic classifications
}

\begin{tabular}{|r|l|}
\hline Journal: & Canadian Journal of Forest Research \\
\hline Manuscript ID & cjfr-2017-0011.R1 \\
\hline Manuscript Type: & Review \\
\hline Date Submitted by the Author: & 31 -Mar-2017 \\
\hline Complete List of Authors: & $\begin{array}{l}\text { Fomin, Valery; Ural State Forest Engineering University, Institute of Forest } \\
\text { and Natural Resource Management } \\
\text { Zalesov, Sergei; Ural State Forest Engineering University, Institute of } \\
\text { Forest and Natural Resource Management } \\
\text { Popov, Artem; Ural State Forest Engineering University, Institute of Forest } \\
\text { and Natural Resource Management } \\
\text { Mikhailovich, Anna; Institute of Physics and Technology, Ural Federal } \\
\text { University, }\end{array}$ \\
\hline Keyword: & $\begin{array}{l}\text { forest typology, ecological, phytocoenotic, genetic, dynamic, forest type } \\
\text { classification, fields of research, Russia }\end{array}$ \\
\hline Please Select from this Special \\
Issues list if applicable:
\end{tabular}

\section{SCHOLARONE}

Manuscripts 
1 Historical avenues of research in Russian forest typology: ecological,

2 phytocoenotic, genetic, and dynamic classifications

3 Fomin V. V., Zalesov S. V., Popov A. S. Institute of Forest and Natural Resource Management,

4 Ural State Forest Engineering University, 620100, Yekaterinburg, Russian Federation, Sibirskiy

$5 \quad$ Trakt, 37

6 Mikhailovich A. P. Institute of Physics and Technology, Ural Federal University, 620002, 19 Mira

7 Street, Yekaterinburg, Russian Federation 


\section{8}

\section{9}

10 European Forest Process. These initiatives are aimed at harmonizing national forest inventory

11 systems with criteria and indicators for sustainable forest management. In Russia, the classification

12 of forest type is at the heart of national forest inventory systems. For various historical reasons,

13 Russian scientific advancements in the field of forest typology remain little known in the rest of the

14 world. This paper is aimed at addressing this deficiency. Here, we provide an overview of the main

15 trends in the field of forest typology studies in the previous political states of the Russian Empire,

16 the Soviet Union, and the Russian Federation from the end of nineteenth to the beginning of the

17 twenty-first centuries. We detail the principles that formed the basis of the most significant forest

18 type classifications. We also perform similarity and differences analyses comparing approaches

19 used by members of different scientific schools in the field of forest typology. The historical

20 relationship between ecological, phytocoenotic, genetic, and dynamic forest type classifications are

21 discussed, as well as the reasons for the prevalence of certain forest type classifications in different

22 regions of Russia.

23 Keywords: forest typology, ecological, phytocoenotic, genetic, dynamic, forest type classification,

24 fields of research, Russia 


\section{Introduction}

The Russian Federation is a member of the Montreal Protocol and the Pan-European Forest Process international agreements (The Montréal Process 1995; 2015; The Pan-European Forest Process 1993). The aim of these initiatives is to harmonize national forest inventory systems to the level of international criteria and indicators for sustainable forest management (Brand 1997;

Castaneda 2000). In Russia, as in many other countries that have acceded to these agreements, the national forest inventory (NFI) system is based on nationally determined concepts of forest types (Chirici et al. 2011). The species composition of tree stands, understory vegetation, and living ground cover, as well as abiotic site factors may be used as criteria for the allocation of a forest to a specific forest type. Forest type classifications result from the collection and organization of information on forests to be used for sustainable forest management (Barbati et al. 2006; Barbati et al. 2007; Barbati et al. 2014).

According to the FAO, the forest area of the Russian Federation constitutes more than half of its total area, and one-fifth of the total area of forests in the world (Forests and the forestry sector, 2003; Annual Report, 2011). Forestry and the forest industry were important elements in the economic structure of the Russian Empire and the USSR in the past (Rogovtseva, 2016), and they remain important in the Russian Federation now. In our country, conceptions of forest type have evolved significantly over the last 150 years, from a view of it as a homogeneous (for some parameters) forest parcel to the concept of forest type as an object in which the homogeneity of origin (genesis), the processes of development and dynamics have a higher priority than homogeneity of forest sites in a space. In other words, from the idea of forest type as an object in space to the idea of forest type as an object in time. Despite significant scientific achievements in the field of forest typology, many aspects of forest-type classifications created by Russian scientists are still little known outside Russia. This may be attributed to the rather long period when Russia was a closed country. 
A comparative analysis of the development of forest type classifications within the main

51 avenues of forest typological studies allows us to trace the convergence of initially different 52 approaches taken by researchers of different scientific schools. This is a good example of 53 harmonization of approaches through a broad scientific discussion at the expert level, leading to a better understanding of alternative points of view and improvements to the forest typology classifications espoused by each. In our view, the harmonization of national forest inventory systems at the level of criteria and indicators for sustainable forest management should also take place in the context of a wider international discussion, primarily at the expert level in the form of publications in international journals, including joint scientific papers. We believe that Russian forest typologies and aspects of their use are still insufficiently known outside Russia. This is the issue that this paper seeks to address.

The aim of this paper is to describe the main avenues of forest typology research followed in Russia since the end of the nineteenth to the beginning of the twenty-first centuries.

\section{Origin of forest typologies in Russia} supported by law. Despite the fact that legal regulation of human relationships with forest use in Russia existed from the eleventh century, the formation of a legislative framework for forest management in the Russian Empire only began from the decree of Peter I (Peter the Great), the first (Peter I 1703) regulated the use and protection of forests for shipbuilding purposes on the basis of qualitative and quantitative criteria (Rogovtseva 2016). This document (Peter I 1703) represents the beginning of regulatory frameworks for forest management in the Russian Empire. However, the notion of forest types and their management in Russian forestry developed much later. (Brain 2011). The first forest type classifications were developed in Germany in the late eighteenth 
to early nineteenth centuries (Luganskiy, et al. 2010; Risin 2009; Scriyabin 1970; Sukachev 1960;

Sukachev 1964). By the end of the nineteenth century and in the early twentieth century, this concept was then adopted by Russian researchers and foresters (Gutorovich 1912; Serebrennikov 1912). Professor G. F. Morozov studied the experience of Russian and German foresters, and concluded that contemporary forestry practices followed an assortment of rules with few of them pertaining to a scientific background. Prof. Morozov decided that this system of rules must be amended to a new branch of knowledge that combined forest management with a scientific understanding of the biological nature of the forest. The name he gave for this discipline was "Lesovedenie" (Kolesnikov 1970), which can roughly translated to Forest Science and Forestry in English.

Morozov created a scientific and theoretical basis for forestry and forest management, with the concept of forest types at the heart of his theory. He used advances from different fields of science: Dokuchaev's genetic soil science, Darwin's theory of evolution, and general knowledge from many branches of botany and geography (Kolesnikov 1970). The results of Prof. G. F. Morozov's research became central to all main forest type classifications that were developed in the Russian Empire, the Soviet Union, and the Russian Federation.

Basic approaches to forest type classification and stages of forest typology development in Russia are described in detail in many papers and books (Denisov 2008; Dylis 1973; Dyrenkov 1989; Ivanova 2010, 2013, 2014; Manko 2013; Morozov 1925; Pogrebnyak 1955; Risin 2009; Sukachev 1957 1972; Smolonogov 1998, 1999). Researchers identify the following periods and main advancements in Russian forest typology research: the period prior to Morozov's study; Morozov's theory of forest types; ecological or ecological-silvicultural forest typology (Krudener's forest type classification; classification of forest types of E. V. Alekseev and P. S. Pogrebnyak); phytocoenotic typology (Sukachev's forest type classification); genetic or geographic and genetic forest typology of B. A. Ivashkevich and B. P. Kolesnikov, as well as Melekhov's dynamic forest typology. 
102

103

104

105

106

107

108

109

110

111

112

113

114

115

116

117

118

119

120

121

122

124

125

126

127

\section{Morozov's theory of forest types}

The understanding that some types of forests occurred in conjunction with specific site conditions and were composed of particular species assemblages existed before the first sciencebased forest type classifications were created. Consequently, the first classifications usually used vernacular names of forest types. The forester G. Gafelder proposed one of the first classifications of forest types for Kurland in 1835 on the basis of the quality of soils (Luganskiy et al. 2010). Some regional forest type classifications were developed in the late nineteenth to early twentieth centuries by the following foresters: G. G. Hartig, A. F. Rudzskiy, N. K. Genko, I. I. Gutorovich,

D. M. Kravchinskii, V. D. Petropavlovskiy, P. P. Serebrennikov, and A. S Rozhnov (Alekseev 1915; Luganskiy et al. 2010; Migunova 2009b; Morozov 1912; Pogrebnyak 1955; Risin 2009). The results of their research and practical experience in creating forest inventories, which is reflected in their classifications of forest types, served as the basis for the theoretical generalizations in the field of forest typology, and the further development of more sophisticated forest typologies.

Prof. Morozov offered a set of fundamentals which were the core of his theory of forest types (Morozov 1925). According to his proposals the classification of forest communities should be based on the following forest-forming factors: 1) ecological properties of tree species; 2) attributes of the geographical environment such as climate, geology, topology, and soil; 3) the biosocial relationship between plants which helped form the forest community, as well as the relationships between plants and animals; 4) historical and geological factors; and 5) human impacts. The last of the described factors was temporarily excluded by Morozov himself from the analysis, but these fundamentals were used by many followers in their forest type classifications. Morozov believed that the grouping of soils on the basis of soil weathering types was one of the key processes, which determined all the other processes. To Morozov (1925), the importance of soil weathering as a soil forming process was clearly evident (Morozov 1925). He also noted the fact that forests were a geographical phenomenon, and that it was necessary to take into account these facts when establishing a classification system for forest types. 
Prof. Morozov also proposed the following hierarchy of units for a classification system:

129

130

131

132

133

134

135

136

137

138

139

140

141

142

143

144

145

146

147

148

149

150

151

152

153

zones, subzones, regions, subregions, forest areas and forest types. The zones and subzones are

arranged more or less in parallel latitudes, whereas regions and subregions may occur across

different latitudes in any direction. He regarded any classification unit as a phenomenon of biogeographical, biosocial, and historical factors, and that the stable existence of a forest is only

possible when its internal processes remain consistent with the geographical environment (Morozov 1925). Ultimately, around the 1920s Morozov developed a system of scientific statements that were important in forming a number of national forest type classifications described below.

Prof. Morozov proposed that schemes based on site conditions be referred to as natural or genetic classifications, whereas those based on other attributes be referred to as artificial schemes (Alekseev 1915). Later this proposal was modified by B. P. Kolesnikov (1961). He suggested the use of three groups of forest type classifications: artificial, natural and genetic (Kolesnikov 1961), which became terms currently in use in Russian forest science.

Classifications that existed in the period prior to Morozov's research relate to the artificial category, whereas natural classification is based on the statements designed by Morozov. The authors of natural classification schemes posit the need to consider the dynamics of forests, but their genesis is not deeply reflected in classification schemas (Kolesnikov 1961). Genetic classifications are more advanced than natural classifications as they are devoid of the latter's inherent shortcomings, yet still take into account genesis as well as different stages of forest dynamics.

Initial ecological avenues of research in forest typology: Krudener's forest type classification

One of the first classifications of forest types based on Morozov's statements was developed by A. A. Krudener (Krudener 1916). This classification adopts an ecological direction of research into the field of forest typology (Migunova 2002). Krudener emphasized soil conditions and built a classification of forest types for European regions of Russia using a deductive method. He divided this area into climatic zones, subzones, regions, and subregions. Zoning was carried out using the following parameters: air humidity and temperature conditions that affect soil forming processes; 
154 minimum and maximum air temperature; the origin and composition of aqueous solutions; water

155 balance; accessibility of nutrients for plants; duration of the growing season; and features of snow

156 cover. He considered that orographic factors have to be automatically taken into account with the

157 use of such zoning in a study area (Krudener 1916).

158 Krudener analyzed geological layers in defined climatic regions in order to understand the

159 genesis and creation of the soil formation in the areas close to the root systems of trees. He then

160 analyzed the soil composition and its water regime according to macro- and micro-relief. He

161 characterized groups of sand, clay, stony deposits and humus, as well as combinations thereof,

162 associated with the relief and water regime. These factors in combination with the forest community

163 determined the type of forest (Krudener 1916).

164 Krudener developed a classification table with a title translated into English as "The main

165 types of soils and typical soil conditions, depending on the moisture (water drainage), air (air

166 drainage) and the nature of the upper soil layer (acidic, neutral, muddy humus, peat), forming

167 certain types of forest due to combination of the mineral substrates and tree stands" (Krudener

168 1916). This table summarizes what he perceived to be the most important classification parameters

169 for forest type determination. Krudener's forest type classification covers a huge area of about seven

170 million hectares, ranging from tundra areas of the Far North to the forests of the Caucasus

171 Mountains. Data sets from six thousand forest plots and the use of a large number of anecdotal

172 descriptions forests were used for building Krudener's typology. This table was used for several

173 decades (Migunova 2002).

174 A generalized schema of Krudener's classification table is shown in Fig. 1. It consists of two

175 parts: the upper part marked with letter $A$, and the bottom part marked with letter $B$. Part A includes

176 five indicators: 1 - hygrometric group, 2 - mineral substrate and soil, 3 - the nature and degree of

177 moisture, as well as drainage, 4 - the nature of the topsoil, and 5 - the access of oxygen to the soil

178 (aeration). Part $A$ has a rather complicated structure. Some of the above five indicators may consist

179 of two to four parts (rows). Vertically, the table is divided into three major groups of indicators: I - 
types of upland meadow terraces, II - floodplain and gallery types, III - types as a result of the rapid

181 or gradual bogging process or reverse process. Part $A$ of the table is an irregular network of cells of

182 different sizes (Fig. 1). This part of the table is shown in Fig. 1 partially because of its large size.

183 The fragment colored gray (Fig. 1) is shown in detail in Fig. 2.

Part $B$ of Krudener's classification table consists of seven rows, which contain petrographic physical-mechanical groups (substrates) and 16 columns, which are combinations of soil and subsoil types (Fig. 1). The groups of these combinations are the following: 1 - sand (for forest type bor in Russian), 2 - sandy loam (or forest type subor in Russian), 3 - clay (or forest type ramen in Russian), 4 - fine sand or sandy sediments underlain by clay substrates (or forest type suramen in Russian), 5 - fine sand or sandy sediments underlain by rocky substrates (or forest type melkiy bor and subor in Russian); 6 - fine loam (clay) deposits underlain by rocky substrates (or forest type melkiy ramen on the rocky substrate); 7 - fine loam (clay) deposits underlain by sandy substrate (or forest type melkiy ramen on a sandy substrate). Krudener chose the vernacular names for groups of soils and subsoil types, which are given in parentheses above. Part $A$. The combination of moisture and air availability of the substrate from the upper part (Part $A)$, to the substrate that is shown in the lower part $(\operatorname{Part} B)$ is a certain type of soil. For example, column three of the lower part (Fig 2) corresponds to the following set of characteristics from the upper part: types of upland meadow terraces with constant moisture, fresh, i.e. moderate humidity with good drainage; with acidic humus; with a lack of air availability in the soil. 
Krudener created the first science-based Russian classification scheme of forest types, using the theoretical statements developed by Prof. Morozov. Krudener's classification played a very important role in the further development of forest type classifications in Russia. The advancements of Krudener have been used by numerous researchers to create their typologies. One of the most well known of these is the classification scheme of A. A. Alekseev-P. S. Pogrebnyak.

Subsequent ecological avenues of research in forest typology: the forest type classification of

\section{E. V. Alekseev and P. S. Pogrebniyak}

The forest type classification of E. V. Alekseev and P. S. Pogrebniyak used ecological (Migunova 2002) and or ecological-silvicultural (Kolesnikov 1974) lines of research. This classification has been developed on the basis of the results of the separate researches performed by forest types for the central part of Ukraine. He defined six groups of forest types using Krudener's classifications of soil conditions, as well as adding the characteristics of stands, undergrowth, and live ground cover (Merzlenko 2005). Subsequently, his line of research was supported by Schepotiev 1970; Sukachev 1957).

The edaphic grid of habitats is used to determine the forest type in the classification scheme of E. V. Alekseev-P. S. Pogrebniyak. Trophic groups are shown on the horizontal axis, groups of soil moisture conditions on the vertical axis (Fig. 3). The trophic groups in the columns differ from each other in nutrient contents, and were referred to as "trophotopes" by Pogrebniyak himself (Pogrebniyak 1955). Each group was designated by a name and letter (A - bor, B - subor, C - mixed subor, D - dubrava), differed from each other by edaphic (soil and subsoil) moistening, and were 227 referred to as "gigrotopes." Each gigrrotope was designated a name and number: 0 - xerophilous 
defined as a combination of trees, living ground cover species, and edatope. The symbols for typical tree species and the names of typical indicators for living ground covers are drawn on the grid. classification model for climate assessment in the form of a grid, the coordinate axes of which are indicators of the heat and humidity of the climate. Within homogeneous climate zones, forest types are determined using an edaphic grid that allows a forester to systematize typological diversity of forests (Migunova, 2002, 2007).

Although the Alekseev-Pogrebnyak classification uses an edaphic grid of habitats, tree stands and living ground cover species for forest type determination, in practice this typology has been widely adopted in regions where particular edatopes correspond, as a rule, to particular types of stand; an edatope type determination on the basis of the edaphic grid is thus sufficient to

\section{4 determine the forest type.}

\section{Phytocoenosis avenues of research in forest typology: Sukachev's forest type classification}

The phytocenosis line of research in forest typology was created by V. N. Sukachev along with his numerous contemporaries (Denisov 2008; Luganskiy et al. 2010). Sukachev made an important statement regarding forest typology, which translates into English as "plant communities that are grouped into types, must have homogeneous direct-impact factors, i.e., must have biologically equivalent habitats" (Sukachev 1972). The difficulty in measuring many of these

251 factors, such as the mineral and water regime of the soil, the soil's oxygen supply, and the 252 interaction of these and other factors which influence the phytocoenosis of huge areas, inspired him 253 to create a forest type classification using indirect measurements of these factors, i.e., using 254 characteristics of forest association. He proposed to use species composition as an associated 255 measurement, the spatial distribution, and developmental stage of species, as well as a set of forest 
256 parameters of tree stands at a certain age: the average diameter, the shape of trunks, stand density, 257 the maximum degree of crown closure, total basal area of trees, and standing crop (Sukachev 1972).

258 One of the most important indicators of forest phytocoenosis is renewal, where a forest type can 259 only be maintained as long as it is ensured forest renewal. Changing the type of phytocoenosis can 260 occur if forest renewal is terminated, or new and different tree species are emerging in the 261 undergrowth. Assessing the similarity of directly acting factors and their levels of impact on 262 phytocoenoses is based on indirect factors: climate, topography, rocks, soil, groundwater level, the 263 environment of the habitat, and human and animal impact (Sukachev 1972).

264 V. N. Sukachev proposed that the determinants of forest type were those species that 265 determine the layering, phenology, and the presence of certain synusiae. These most important 266 species should play an important role in the composition of each layer and its phenology. The 267 homogeneity of the properties of a phytocoenosis that unite it into one forest type necessitates the application of the same forest management practices. The usefulness of a phytocoenosis is based on the natural and economic conditions. Sukachev proposed to use two kinds of parameters that could reveal forest units: natural-historical and economical.

Defining homogeneous forest areas based on a range of natural and historical factors was more important than defining them based on economic factors, as grouping forest parcels into management units on the basis of economic categories depended upon potentially short-term economic goals. Therefore, forest type in the interpretation of V. N. Sukachev was a naturalhistorical concept (Sukachev 1972), independent from the viewpoint of economic purposes. association of forest parcels (i.e. forest ecosystems), homogeneous in composition of tree species, 278 other vegetation levels, fauna, a range of site quality conditions (climate, soil and hydrological), the relationship between plants and the environment, forest reproduction processes, and corresponding 
281

282

economic conditions. A type of forest under these conditions can therefore be considered as a type of forest biogeocenosis (Sukachev 1972).

Under particular forest site quality conditions Sukachev understood the following: the area possesses a uniform set of ecological factors (climatic and soil-hydrological) affecting plant growth. However, within an area the same type of site quality conditions can support several forest types, yet at the same time, each forest type has its own specific set of soil and climatic conditions, as these are dependent upon the vegetation that is present (Sukachev 1957).

Climate, soil, and vegetation influence each other. Excluding anthropogenic factors, it is possible to identify two groups of factors that are linked to climate and soil. V. N. Sukachev believed that inclusive of all edaphic conditions, the most important in terms of the effects on plants is soil chemistry, followed by moisture and aeration. The concentrations of beneficial and harmful minerals, which effect soil acidity, are the most ecologically significant for plants out of all the chemical properties of soil. Within a homogeneous climatic zone, soil reaction is determined by the mineral composition and humidity, i.e., salt and water regimes are the predominant edaphic factors. The third important factor mentioned above, is soil oxygen supply. It depends on soil aeration, which is mostly inversely related to drainage. However, even in conditions of excessive moisture the soil can be sufficiently provided with oxygen as long as water is able to move through the soil.

$$
\text { A variety of combinations of these three factors for boreal forests is limited. The high }
$$
relative humidity of this climate zone leads to the prevalence of wet soils and a lack of extremely dry soils. These soils are generally leached, and their nutrient status depends on their humidity and mechanical consistency. Excessive stagnant moisture in the soil leads to the formation of peaty soils with a reduced availability of nutrients. Dry soils on the other hand are leached to a lower extent, and consequently contain more nutrients.

V. N. Sukachev developed a generalized classification scheme for the combination of factors described above. This scheme is divided into four quarters (Fig. 4). The first quarter corresponds to loamy, well-drained soils. The second quarter corresponds to overflowing moist soils with an 
307 adequate supply of nutrients and oxygen, and a neutral or acidic soil solution. The third quarter

308 corresponds to excessively wet and poorly drained soil with a minimal amount of minerals available

309 to plants, and a $\mathrm{pH}$ lower than 7. The fourth quarter corresponds to dry and well-drained soils with

310 low acidity and good aeration (Sukachev 1972).

311 The understory vegetation may be a good indicator of the impact of complex direct acting

312 factors (Cajander 1933). V. N. Sukachev suggested the use of genus names of trees and full species

313 names of herbaceous and shrubby plants, as well as some parameters of site quality conditions, such

314 as the structure of tree layers in a forest type name.

315 Sukachev's forest type classification was widely used in different regions of the Soviet

316 Union, especially in the lowland forests of the taiga and steppe zones of the European area of

317 Russia. Sukachev's scheme represented the creation of the final stage of a natural classification of

318 forest types in the Russian Empire and the USSR.

319 Genetic avenues in forest type classifications

320 Large-scale industrial use of forests has led to a decrease in the area of natural forests and to

321 an increasing role for anthropogenic forests. Classical approaches to classifying natural forest types

322 (relatively stable and homogeneous) became insufficient for considering their anthropogenic

323 dynamics. Consequently, natural classifications have been replaced by more sophisticated genetic

324 classifications of forest types (Kolesnikov 1974).

325 The first attempt to create a genetic classification of forest types was made by

326 B. A. Ivashkevich for the forests of the Far East of the USSR (Kolesnikov 1961, Manko 2009,

327 2013). However, the principles that formed the basis of the genetic approach for forest type

328 classifications were formulated in 1905 by an unknown author under the pseudonym of "Doubting"

329 (Smolonogov 1998). Later, research in the field of genetic typology was continued by A. S.

330 Yablokov, A. A. Molchanov, A. K. Denisov, and V. V. Popov (Kolesnikov 1961).

331 The term genetic classification of forest types was introduced by B. A. Ivashkevich in 1923

332 (Manko 2013). The term genetic emphasizes the genesis of types of forest biogeocoenosis in this 
333 forest typology, i.e., priority of successional changes of one biogeocoenosis over other ones (Manko 334 2009). In addition, the heritability of forest structure is understood at the phytocoenosis level rather 335 than at the individual or population-genetic levels (Sannikov 2009; Sannikov et al. 2012).

336 The basis of the genetic approach to the classification of forest types is the concept of forest 337 forming processes, which covers all forms of the Earth's forest cover over time (Kolesnikov 1974;

338 Smolonogov 1995a). Forest forming processes include the well-known global processes related to 339 the emergence, dynamics and destruction of forest vegetation under the influence of endogenous 340 and exogenous factors (Manko 2012). The processes of development and dynamics plays a more 341 important role in genetic forest type classifications than the homogeneity of stand composition, 342 structure and other parameters, which are used for forest type identification in natural 343 classifications. A forest type defined in the framework of the genetic approach is seen as a stage of 344 the forest forming process. At the same time, morphological homogeneity of forest parcels may 345 comprise the individual stages of the development of forest types based on the interpretation of 346 B. A. Ivashkevich and B. P. Kolesnikov. According to B. P. Kolesnikov, a forest forming process is expressed in the following forms of forest succession: 1) age succession, observed over a period of ontogenesis of one forest 349 generation; 2) recovery succession, due to the strong impact of exogenous factors (fire, storm 350 damage, forest felling, insect infestations); 3) alluvial succession; and 4) centuries-old or 351 phylogenetic succession. The concept of indigenous and secondary forest types has existed in 352 natural forest types classifications. However, only the genetic classification scheme includes the 353 relationship between forest types in the form of a successional series of phytocoenoses through 354 time.

B. P. Kolesnikov defined the following changes in phytocoenosis under a genetic scheme: naturally reversible short-term and long-term recovery successions, as well as naturally irreversible 357 succession. After exogenous impacts on an indigenous phytocoenosis the first two types of 358 reversible successions return it to their original type. These successions display different durations 
359 of time intervals. Irreversible succession changes from an indigenous forest type to a stable

360 secondary forest phytocoenosis.

$361 \quad$ Kolesnikov provided a scientific basis for the selection of the following three forest forming

362 periods in Russia: forests existing before agricultural effects; existing forests which have been

363 spontaneously used by humans; forests that were planned for human use (Kolesnikov 1961;

364 Smolonogov 1995b). These classes allow researchers to take into account the level of anthropogenic

365 impact on forests used in research. The use of these forest classes was due to the need to take into

366 account specific features of forest forming processes from different eras in human history. He also

367 developed a classification of taiga zone forests with regard to the human impacts they have been

368 subjected to (Kolesnikov 1974). At its core, this scheme consists of three major classes: virgin

369 forests, undisturbed forests, and modern forests.

B. P Kolesnikov (1974) gives the following definition of the forest type: forest type is

defined as a stage of forest formation (biogeocoenotic, evolutionary) that takes place within the boundaries of a certain type of site condition (type of ecotope), on the territory of a particular (physical and geographical) region, over a period equal to at least one generation of forest forming species. In his opinion, the analysis of forest type should be implemented on the basis of the relatively stable parameter of the generational time of a dominant forest species, i.e., from birth to death, in an area relating to a specific type of forest site condition. Forest type in the genetic classification consists of a series of biogeocoenoses succeeding one another in time (Kolesnikov, et. 378 al. 1974). considered as synonyms, whereas a forest type in the genetic classification is a broader concept.

381 Forest type in the genetic typology corresponds to the set of forest biogeocoenoses over time, i.e., the set of types of forest in the interpretation of V. N. Sukachev (Smolonogov 1998). 
B. P. Kolesnikov used the achievements of Sukachev's classification. Sukachev's forest types were used as stages of development for the current versions of Ivashkevich's and Kolesnikov's genetic typology. Thus, in the classification scheme of the genetic typology the duration and direction of different types of successional changes for each Kolesnikov's forest types is shown.

In the classification systems of biogeocoenosis combined with practical typologies, systematic units can be applied in the form of geographical and chorological areas (TimofeevResovskii 1961). This principle is also used in genetic forest typologies. For example, unlike Sukachev's phytocoenotic classification, genetic forest typologies are strictly regional (Sochava 1961; Smagin 1973). Consequently, before the creation of classification scheme for forest types, zoning territory according to the influence of complex factors on forests was the common practice. Schemes of forest types created for low-level taxonomic units were created in such a way as to facilitate this (Kolesnikov et al. 1974; Sedikh 2005; Smolonogov 1995a).

The genetic approach to the classification of forest types have only been briefly described above. To consider the principles underlying the genetic approach, annotate the findings of practitioners in this field, and to consider prospects for future developments would require a separate publication.

\section{Dynamic avenues of research in forest type classification}

$$
\text { Not considering the anthropogenic factors that impact on the dynamics of forests is a }
$$

shortcoming of natural typologies. I. S. Melekhov proposed a forest type classification on the basis of Sukachev's typology. His point of view on what constitutes a type of forest is similar in concept to the genetic typology of B. A. Ivashkevich and B. P. Kolesnikov. He believed that the forest type should be considered in space and time, i.e., it is a stage or series of stages in the development of the forest (Harin et al. 2005; Luganskiy et al. 2010). The dynamic typology takes into account exogenous and endogenous changes in the forest, accounting for the possibility of a transition from one forest type to another, as well as the relationships between the stages within the same forest type. Successional changes on clearings are the result of regeneration changes. Regeneration of the 
411 initial stage corresponds to the type of felling, which is determined by a combination of forest

412 conditions, evaluated using parameters of plant associations, which depends on the original type of

413 forest present before timber felling took place (Ulanova 2009).

414 I. S. Melekhov distinguishes the following stages of forest development: the stage prior to

415 the formation of forests (types of forest felling and burnt places); the stage of forest formation; the

416 stage of a mature forest; subsequent stages comprising new types of forests (Sennov and Griyazkin

417 2006). Dynamic classification - unlike the classification of B. A. Ivashkevich-B. P. Kolesnikov-is

418 not used as a deterministic scheme for changes of forest types.

419 B. P. Kolesnikov believed that I. S. Melekhov's classification of types of felling and burnt

420 forest areas (Melekhov 1961), was a special case for the classification of the initial stages of

421 reforestation in the course of their developmental regeneration changes, or digressive stable

422 successions, therefore Meklehov's dynamic classification can be attributed to genetic forest type

423 classifications (Kolesnikov 1974).

\section{Regional specificities in the use of forest type classifications in Russia}

425 Almost all the classifications described above, with the exception of Krudener's forest

426 typology, are currently in use in forestry and forest management in the Russian Federation and

427 neighboring countries (former Soviet republics). In different regions of Russia, one of the

428 classifications described above usually prevails. This is due to the following reasons: differences in

429 the influence of environmental factors on vegetation cover; regional characteristics of forest

430 management; the history of scientific schools in the field of forest typology (Farber 2014; Ivanov et

431 al. 2012; Ivanova 2011; Kolesnikov 1974).

432 In the taiga zone, forest inventories were carried out mostly in untouched forests, so the

433 features of undisturbed living ground cover in combination with the position of the forest parcels in

434 the relief allowed a forester to receive an objective description of soil conditions from the beginning

435 of data collection. Sukachev's classification is very suitable for such forests (Ivanov et al. 2012). 
in the forest-steppe regions of Russia (Senov and Griyazkin 2006). In Ukraine, forest site conditions depend to a great extent on soil fertility (Farber 2014). In addition, artificial restoration of disturbed forests after felling, fires, plowing, soil erosion, grazing, and mowing are very important tasks. Live ground cover in these forests does not represent the history of soil conditions. Under these circumstances, researchers and foresters were focused on the identification of trophic levels and soil moisture, the species composition of forest stands, and the potential for generating sustainable and productive forests (Ivanov et al. 2012).

Principles of forest classification designed for the lowland forests of the taiga and foreststeppe zones of the European part of the USSR did not give satisfactory results for the mountain multispecies mixed forests of the Manchurian botanical-geographical region of the Far East (Kolesnikov, 1956). B. A. Ivashkevich noted that the diversity of forests in even a small area of this region - about 1000 square kilometers, say - is no less than in the entire forest belt of the European part of Russia (Kolesnikov, 1956). The genetic approach to forest-type classification allowed B. A. Ivashkevich to solve this problem. He created the first genetic forest-type classification for mountain and valley forests in the Far East (Manko, 2013). His disciple and follower B. P. Kolesnikov developed Ivashkevich's ideas of the genetic approach in forest typology. They have been successfully used to create classifications of types of forest in the Urals and in the mountainous regions of Siberia, as well as classifications for cedar (pine apple) forests in the Far East.

The characteristics of the main forest type classifications in the Russian Federation are given in the table. The data in this table enables comparison of the classifications by a number of key 458 indicators: the scope of the term "forest type", the parameters used to determine forest type, the account taken of succession dynamics and the effect of a number of anthropogenic factors, as well 
A series of all-USSR and All-Russian meetings and conferences of forest scientists and

463

foresters was held from the fifties to the early nineties of the twentieth century. They tried to unify their positions on the different forest-type classifications and create a single forest typology (Dyrenkov, 1989; Manko 2012; Rysin, 2009; Farber 2014). This consensus had not been reached, despite the convergence of some positions on specific issues. However, in the course of scientific discussions lasting several decades, there was a significant rapprochement of the positions of different scientific schools, allowing researchers to propose improvements and create more sophisticated forest typologies. We consider the genetic forest type classification of B. A. Ivashkevich and B. P. Kolesnikov one of the most advanced forest typologies in the Russian Federation today, one that takes account of the progress made in the area of forest type classifications.

\section{Conclusion}

Forest typology in the Russian Empire and later in the Soviet Union and the Russian Federation has gone from empirical, strictly applied classifications of forest types to theories based on a complex scientific discipline. Understandings of forest types evolved from the concept of homogeneous forest parcels in space to the concept of the forest type as a series of closely interrelated stages of forest development in time - i.e., genetic types of biogeocoenosis within a forest type. It has formed several lines of research and created the following forest type classifications: ecological or ecological-silvicultural (classifications of A. A. Krudener and E. V. Alekseev-P. S. Pogrebnyak); phytocoenotic (classification of Sukachev); genetic (classification of B. A. Ivashkevich and B. P. Kolesnikov); and dynamic (classification of I. S. Melekhov).

In the ecological and phytocenotic approaches in the field of forest typology, a type of forest is considered as spatial entity, i.e. they view forests on the basis of their homogeneity in space. Forest-type classifications based on these approaches are called natural. In E. V. Alekseev and P. S. Pogrebnyak's classification, more attention was paid to the determination of site conditions. In V. 
N. Sukachev's phytocenotic classification, greater attention was paid to description of phytocoenosis components and identification of live ground cover species or other characteristics of the site conditions. Later, the Alekseev- Pogrebnyak classification also developed in the direction of taking account of regional specifics in the growth of forest vegetation, and taking account of succession dynamics. V. N. Sukachev did a large amount of productive work on the study of successional dynamics of forest communities, but in his classification they figured, essentially, only as a number of theoretical propositions.

Forest typologies that support the view of a forest type as a spatio-temporal entity are called genetic. This term is used because in these typologies genesis and the similarity of the processes of forest development have priority over homogeneity (morphological uniformity) of forest parcels. The forest-type classifications of B. A. Ivashkevich and B. P. Kolesnikov, and the dynamic classification of I. S. Melekhov, meet these requirements. A number of significant shortcomings of natural typologies were eliminated in genetic and dynamic typologies. This applies above all to the account taken of recovery and age succession in the forest, as well as to the impact of some anthropogenic factors.

The development of forest typologies in Russia, which took place within a broad scientific discussion, is an example of a harmonization process encouraging the development of forest type classifications within the main directions of forest typological research. The harmonization of national forest inventory systems at the level of criteria and indicators for sustainable forest management should also take place in the context of broad international discussions. It will enable a better understanding of the features of national forest inventory systems used in different countries, and enable individual countries to adopt the most advanced features of equivalents in other countries when improving their own forest inventory and management systems.

\section{Acknowledgements}


number 15-04-05857A) and the Ministry of Education and Science (project №2001 and

514 №37.8872.2017/BCH).

\section{References}

Alekseev, E. V. 1915. Forest types of and their relation to the site and economic classes in

Zhurnal, 1915].

Annual Report on the state and use of forests in the Russian Federation [Translated from

Ezhegodniy doklad o sostoyanii i ispolsovanii lesov Rossiaskoi Federatsii za 2011 god, 2011]

[online] Available from http://www.mnr.gov.ru/upload/iblock/780/lesarf2011.pdf [accessed 21

522

523

524

525

526

528

529

530

531

532
March 2017].

Bakhsoliani, T. G. and Svanidze, M. A. 1973. About dynamic types of Transcaucasus

Forests. Questions of Forestry, 2: pp. 114-121. [Translated from Russian from Voprosi

Lesovedeniya, 1973].

Barbati, A., Corona, P., and Marchetti, M. 2006. European forest types Categories and types for sustainable forest management reporting and policy. EEA Technical report, No 9/2006.

Barbati, A., Corona, P., and Marchetti, M. 2007. A forest typology for monitoring sustainable forest management: The case of European Forest Types. Plant Biosystems, 141(1): 93 103. doi: $10.1080 / 11263500601153842$

Barbati, A., Marchetti, M., Chirici, G., and Corona, P. 2014. European Forest Types and Forest Europe SFM indicators: Tools for monitoring progress on forest biodiversity conservation. Forest Ecology and Management, 321: 145-157.

Brand, D. G. 1997. Criteria and indicators for the conservation and sustainable management of Forest: progress to date and future directions. Biomass and Bioenergy, 13(4/5): 247-253.

Brain, S. 2011. Song of the Forest: Russian Forestry and Stalinist Environmentalism, 19051953. Pittsburgh: University of Pittsburgh Press. 232 p. 
Cajander, A. K. 1933. The essence and meaning of forest types. Goslestekhizdat, 1933. pp.

539

3-49. [Translated from Russian by S. S. Arkhipov and N. K. Karakash of the Book Cajander A. K

Wesen und Bedeutung der Waldtypen. Nach drei Vorträgen in Dorpat 1927. Trükikoda Ed.

Bergmann, Tartus (Dorpat). 1927].

Castañeda, F. 2000. Criteria and indicators for sustainable forest management: international processes, current status and the way ahead. Unasylva 203(51): 34-40.

Chirici, G., Winter, S., and McRoberts, R. E. (Editors) 2011. National Forest Inventories:

Contributions to Forest Biodiversity Assessments. Managing Forest Ecosystems, Vol. 20.

Farber, S. K. 2014. Structuring of forest communities. Siberian Journal of Forest Science,1:

35-49. [Translated from Russian from Sibirskiy lesnoy zhurnal, 2014].

Forests and the forestry sector. 2003. Russian Federation [online]. Available from http://www.fao.org/forestry/country/57478/en/rus/ [accessed 03 November 2016].

Gutorovich, I. I. 1912. Краткое описание типов насаждений, встречаемых в Вятской и Пермской губерниях, в северных их частях. Forestry Journal, 4(5): 502-512. [Translated from Russian from Lesnoy Zhurnal, 1912].

Denisov, S. A. 2008. Forestry. Yoshkar-Ola: Mari State Technical University. 168 p.

[Translated from Russian from Denisov S. A. Lesovedenie, 2008].

Dyrenkov, S. A. 1989. About regional cadasters of forest types. Russian Journal of Forest

Science, 2: 3-9. [Translated from Russian from Lesovedenie, 1989].

Dylis, N. V. 1973. The influence of V. N. Sukachev's ideas for the development of the Soviet Forestry. Quest. For. 2: 5-14. [Translated from Russian from Voprosi Lesovedeniya, 1973].

Ivanov, V. A., Kalenskaya, O. P., Luzganov, A. G., and Buriak, L. V. 2012. The main forest types of Siberia. Krasnoyarsk: Красноярск: Siberian State Technological University 140 p.

[Translated from Russian from Osnovnie tipi lesa Sibiri, 2012]. 
Ivanova, N. S. 2010. The development of genetic forest typology in Russia. Mo. High

563

Technol. 12: 94-95. [Translated from Russian from Sovremenniye naukoemkie tekhnologii v Rossii, 2010].

Ivanova, N. S. 2011. Biogeocenotic and genetic approaches in forest typology. In Proceedings of the conference: Topical problem of science and education, Russian Federation, Moskow, $18^{\text {th }}-20^{\text {th }}$ April 2011. pp. 8 - 9. [Translated from Russian from Proceeding of the conference: Aktualnie voprosi nfuki i obrazovaniya, 2011]. Ivanova, N. S. 2013. Internet resource: Genetic typology and forests dynamics. Fundam. Res. 1: 576-579. [Translated from Russian from Fundamentalnie issledovaniya, 2013]. Ivanova, N. S. and Zolotova, E. S. 2014. Development of Forest Typology in Russia. Int. J. Bioresour. Stress Manag. 5(2): 298-303. Karazia, S. P. 2009. Reflection processes of forest development in the typological forest classification of Lithuania. In Proceeding of the conference: Genetic typology, dynamics and geography of Russian forests, Russian Federation, Yekaterinburg, UB of Russian Academy of Sciences, 21-24 June 2009. pp. 54-56. [Translated from Russian by Proceeding of the conference: Geneticheskaya tipologia lesov, 2009].

Kharin, O. A., Kozhukhov, N. I., Obidennikov, V. I., and Sergeeva, E. P. Scientific school of Academician of the Russian Academy of Agricultural Sciences (former All-Union Academy of Agricultural Sciences of the USSR) Ivan Stepanovich Melekhov. For. J. 4: 26-34 [Translated from Russian from Lesnoy Zhurnal, 2005].

Kolesnikov, B. P. 1956. Cedar forests of the Far East. Available from Proceedings of the Far Eastern branch of the Academy of Sciences of the USSR. Botanical Series, 2(4): 261 [Translated from Russian from Kedrovie lesa Dalnego Vostoka. Trudi Dalnevostochnogo filiala Akademii nauk SSSR, 1956].

Kolesnikov, B. P. 1961. Genetic classification of forest types and its tasks in the Urals. Available from Proceedings of the Institute of Biology of the Ural branch of the Academy of 
Sciences of the USSR, 27: 47-59. [Translated from Russian from Geneticheskaya tipologia lesov I ee zadachi na Urale. Trudi Instituta biologii Uralskogo filiala AN SSSR, 1967].

Kolesnikov, B. P. and Filroze, E. M. 1967. Application of mensurational description with statistical method and the genetic classification of forest types. Russian J. For. Sci. 4: 16-25. [Translated from Russian from Lesovedenie, 1967].

Kolesnikov, B. P. 1974. Genetic stage in forest typology and its objectives. Russian J. For. Sci. 2: 3-20. [Translated from Russian by Lesovedenie, 1974].

Kolesnikov, B. P., Zubareva, R. S., and Smolonogov, E. P. 1974. Forest growth conditions and forest types of the Sverdlovsk region. Sverdlovsk: UNC of Academy of Sciences of the USSRю 176 p. [Translated from Russian from Lesorastitelnie uslovia b tipi lesov Sverdlovskoi oblasti, 1974].

Kolesnikov, B. P. 1970. G. F. Morozov - the founder of Forest Science and Forestry. In Forest formation processes in the Urals. Edited by Kolesnikov B. P. and G. E. Komin. Sverdlovsk. pp. 203 - 229. [Translated from Russian from Lesoobrazovatelnie processi na Urale, 1970].

Krudener, A. A. 1916. Fundamentals of forest types classification of their practical importance for the national economy. Materials for the Study of Russian forests: a supplement to the Forestry Journal, 3: 190 [Translated from Russian from Materiali po izucheniyu russkogo lesa: prilozhenie k Lesnomu Zurnalu, 1916].

Luganskiy, N. A., Zalesov, S. V., and Luganskiy, V. N. 2010. Forestry. Yekaterinburg: Ural State Forest Engineering University. 432 p. [Translated from Russian from Lesovedenie, 2010]. Manko, Yu. I. 2009. An outstanding researcher of the Far East forests (to the 120th anniversary of B. A. Ivashkevich), Bull. Far Eastern Branch Russian Acad. Sci. 3: 134-140. [Translated from Russian from Vestnik DVO RAN, 2009]. Manko, Yu. I. 2012. B. P. Kolesnikov contribution to the theory of forest forming process and classification of vegetation. In Proceeding of the V All-Russian conference: The forests of the Russian Far East: Monitoring the dynamics of the Russian Far East forests, Vladivostok, 18-20 
614 September 2012. pp. 4- 10. [Translated from Russian from Lesa Rossiskogo Dalnego Vostoka:

615 Monitoring dinamiki lesov Rossiskogo Dalnego Vostoka, 2012].

616 Manko, Yu. I. 2013. The emergence and formation of the genetic forest typology. Russian J.

617 For. Sci. 2: 40-55. [Translated from Russian from Lesovedenie, 1989].

618 Melekhov, I. S. 1961. Vegetation classification and concentrated forest felling. Available 619 from Proceedings of the Institute of Biology, 27: 139-145. [Translated from Russian from Trudi 620 Instituta biologii, 1961].

Merzlenko, M. D. 2005. Evgeniy Venediktovich Alekseev. Sust. For. Management, 1(7): 47-

48. [Translated from Russian from Ustoichivie lesopolzovanie, 2005].

Migunova, E. S. 2002. Development of ideas of G. F. Morozov and A. A. Krudener by

624

625

626

627

628

629

630

631

632

633

634

635

636

637

638

Ukrainian foresters. For. Bull. 2: 131-146. [Translated from Russian from Lesnoy vestnik, 2002].

Migunova, E. S. 2007. Stages of development of Morozov's forest typology school. For.

Bull. 2: 60-67. [Translated from Russian from Lesnoy vestnik, 2007].

Migunova, E. S. 2009a. Type of forest as a taxon in forest typology. For. Agrofor. 116: 108-

119. [Translated from Russian from Lesovodstvo i agrolesomelioratsiya, 2009].

Migunova, E. S. 2009b. Founders of forest-types classification: A. A. Krudener and

E. V. Alekseev. Forestry, 2: 13-14. [Translated from Russian from Lesnoie khoziyaistvo, 2009].

Morozov, G. F. 1912. Type and bonitets. Forest Journal, 6(7): 843-871. [Translated from

Russian from Lesnoy zhurnal, 1912].

Morozov, G. F. 1925. Theory of forest types. Leningrad: State Publishing House. 367 p.

[Translated from Russian from Ucheniye o tipakh lesa, 1925].

Peter I. 1703. About the inventory of forests in all cities and districts, away from large rivers

- 50, and from small rivers - 20 verst: it is a decree of His Imperial Majesty on November 19, 1703,

number 1950. [Translated from Russian from Imennoy ukaz Ego Imperatorskogo Velichestva

nomer 1950, 1703]. 

Academy of Sciences of the Ukrainian SSR 452 p. [Translated from Russian from Osnovi lesnoi 641 tipologii, 1968]. Russian from Obschee lesovodstvo, 1968].

Risin, L. P. 2009. Is there a future of forest typology in Russia? In Proceeding of the All-

Russian conference: Forest resources of Russian Taiga: forest Use and reforestation problems.

Petrozavodsk. Russian Federation, 30 September - 03 October 2009. pp. 8-10. [Translated from

647 Proceeding of the conference: Lesnie resursi taezhnoi zoni Rossii: problemi lesopolzovaniya i

648 lesovosstanovleniya, 2009].

Rizhkova, V. A., Korets, M. A., and Danilova, I. V. 2009. Mapping of forest cover on the basis of genetic typology using GIS? In Proceeding of the All-Russian conference: Genetic typology, dynamics and geography of Russian forests, Yekaterinburg, 21 - 24 July 2009. pp. 184 187. [Translated from Russian from Geneticheskaya tipologiya, dinamika I geographiya lesov, $6532009]$.

Ryzhkova, V., Danilova, I., and Korets, M. 2011. A GIS-based mapping and estimation the current forest landscape state and dynamics. J. Landscape Ecol. 4(1): 42-54. thesis. Institute of Law, National Research Tomsk State University, Tomsk, the Russian Federation. 658 [Translated from Russian from Stanovlenie i razvitie lesnogo zakonodatelstva, 2016]. Sannikov, S. N. 2009. Divergence, convergence, and inheritance of structure of forest 660 biogeocenosis. In Proceeding of the conference: Genetic typology, dynamics and geography of 661 Russian forests, Russian Federation, Yekaterinburg, UB of Russian Academy of Sciences, 21-24 662 June 2009. pp. 56-61. [Translated from Russian by Proceeding of the conference: Geneticheskaya 663 tipologia lesov, 2009]. 

population biology. Yekaterinburg: Botanic garden of the Ural Branch of the Russian Academy of

666

667

668

669

670

671

672

673

674

675

676

677

678

679

680

681

682

683

684

685

686

687

688

689

Sciences. 271 p.

Senov, S. N. and Griyazkin, A. V. 2006. Forestry: learning guide. Sankt-Peterburg:

SpbGLTA. 70 p.

Schepotiev, F. L. 1970. E. V. Alekseev (the 100th anniversary). Russian J. For. Sci. 4: 10-13.

[Translated from Russian from Lesovedenie, 1970].

Sedikh, V. N. 2005. Landscape-typological basis for forest inventory in Siberia. For. Tax.

For. Inv. 1(34): 70-77. [Translated from Russian from Lesnaya taksatsiya i lesousntroistvo, 2005].

Serebrennikov, P. P. 1912. About forest types their significance in the northern forestry.

Velsk: Samoilov's printing house. 40 p. [Translated from Russian from O tipakh nasazhdenii i ikh

znachenii v severnom lesnom khoziyastve, 1912].

Skriyabin, M. P. 1970. G. F. Morozov and some problems of forest science. In Forest-

forming processes in the Urals. Edited by. B. P. Kolesnikov and G. E. Komin. Sverdlovsk. pp. 15-

21. [Translated from Russian from Lesoobrazovatelniye processi na Urale, 1970].

Smagin, V. N. 1973. Actual questions of forest typology. Volume 2. In Questions of Forestry.

Edited by Zhukov A. B. Krasnoyarsk. pp. 15-26. [Translated from Russian from Voprosi

lesovedeniya, 1973].

Smolonogov, E. P. 1995a. Comprehensive zoning of the Urals. The forests of the Urals and forest management in them. 18: 24-42. [Translated from Russian from Lesa Urala i Khoziyastvo v nikh, 1995].

Smolonogov, E. P. 1995b. Forest-forming process and genetic classification of forest types. The forests of the Urals and forest management in them. 18: 43-58. [Translated from Russian from Lesa Urala i Khoziyastvo v nikh, 1995].

Smolonogov, E. P. 1998. Main principles of the genetic approach to the typological classification of forests. Russian J. Ecol. 29(4): 220-225. 
691 from Russian from Lesnoy Zhurnal, 1999]. geographical facies and biogeocenosis. Vegetation Classification and geobotanical cartography. Available from Proceedings of the Institute of Biology. 27: 5-22. [Translated from Russian from Trudi Instituta biologii, 1961].

Sukachev, V. N. 1957. The development of forest typology in the USSR for 40 years. In The achievements of science in forestry for 40 years. Edited by Sukachev V. N., Nikitin I. I.,

Vasiliev P. V. Moskow.Leningrad. Goslesbumizdat. pp. 5-16. [Translated from Russian from

Dostizheniya nauki v lesnom khoziastve za 40 let, 1957].

Sukachev, V. N. 1960. Forest biogeocenology as the theoretical basis of forestry and forest

fromVoprosi lesovedenia i lesovodsnva (dokladi na piatom lesnom kongresse), 1960]. biogeotsenologii, 1972]. Management of Temperate and Boreal Forests [online]. Available from_

711 http://www.fao.org/docrep/004/ac135e/ac135e08.htm [assessed 03 November 2016]. 
717 Management [online]. Available from http:/www.fao.org/docrep/004/AC135E/ac135e09.htm

718 [assessed 03 November 2016].

719 Timofeev-Resovskiy, N. V. 1961. About some principles of biochorological units

720 classification. Available from Proceedings of the Institute of Biology, 27: 23-28. [Translated from

721 Russian from Trudi Instituta biologii, 1961].

722 Tiyapkin, M. O. 2014. The origin of forest law and forest management system in Russia in

723 the first quarter of XVIIIth century. Altai Law Bulletin, 4(8): 15-20. [Translated from Russian from

724 Altaiskiy yuridicheskiy vestnik, 2014].

725 Ulanova, N. G. 2009. Synthesis of vegetation classifications of felling sites in the spruce

726 forests of southern taiga according to positions of I. S. Melekhov, V. N. Sukachev, B. P. Kolesnikov

727 and J. Braun-Blanquet. In Proceeding of the conference: Genetic typology, dynamics and geography

728 of Russian forests, Russian Federation, Yekaterinburg, UB of Russian Academy of Sciences, 21-24

729 June 2009. pp. 72-75. [Translated from Russian by Proceeding of the conference: Geneticheskaya

730 tipologia lesov, 2009]. 


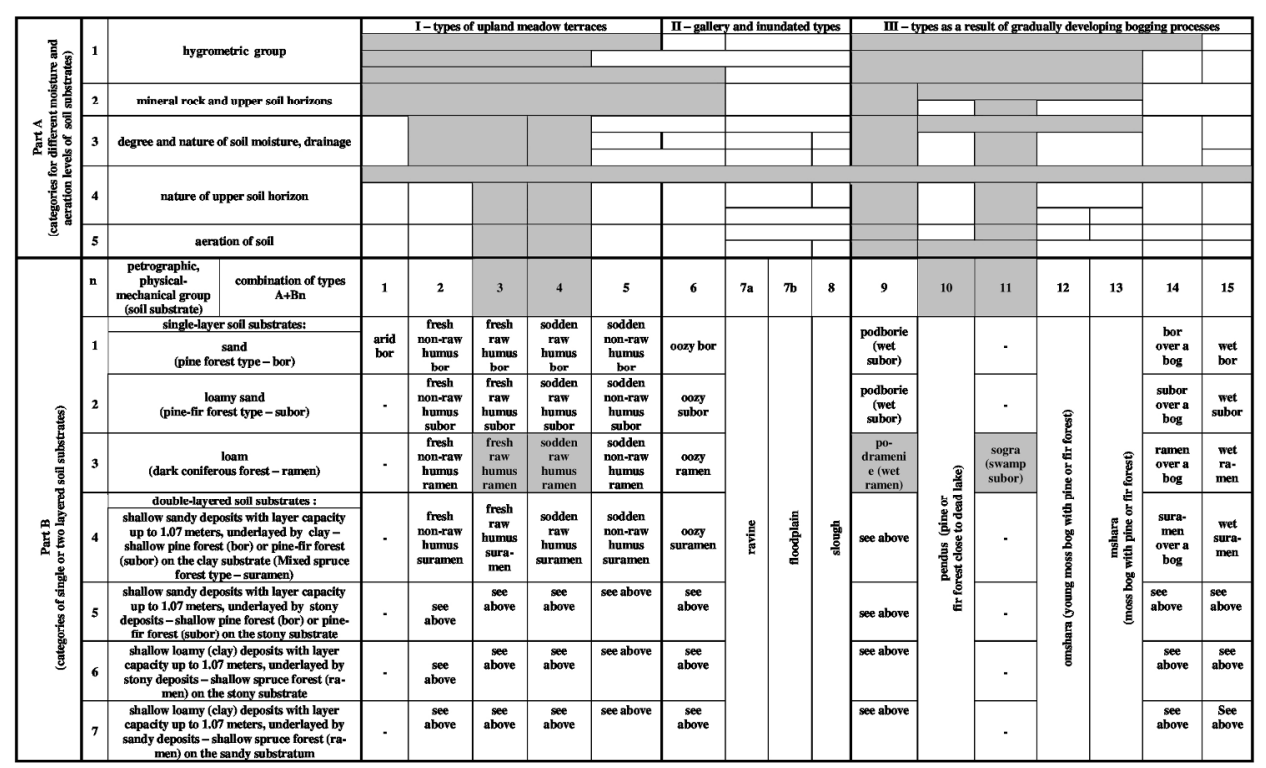

Fig. 1. Generalized scheme of Krudener's classification table of types of habitat conditions and forest types (Krudener, 1916). The figure is an irregular grid comprising cells of different sizes. Owing to the large size of Krudener's original table, we have left the upper part un-filled. These cells are colored gray, and their contents are shown in Fig. 2.

$296 \times 209 \mathrm{~mm}(200 \times 200$ DPI $)$ 


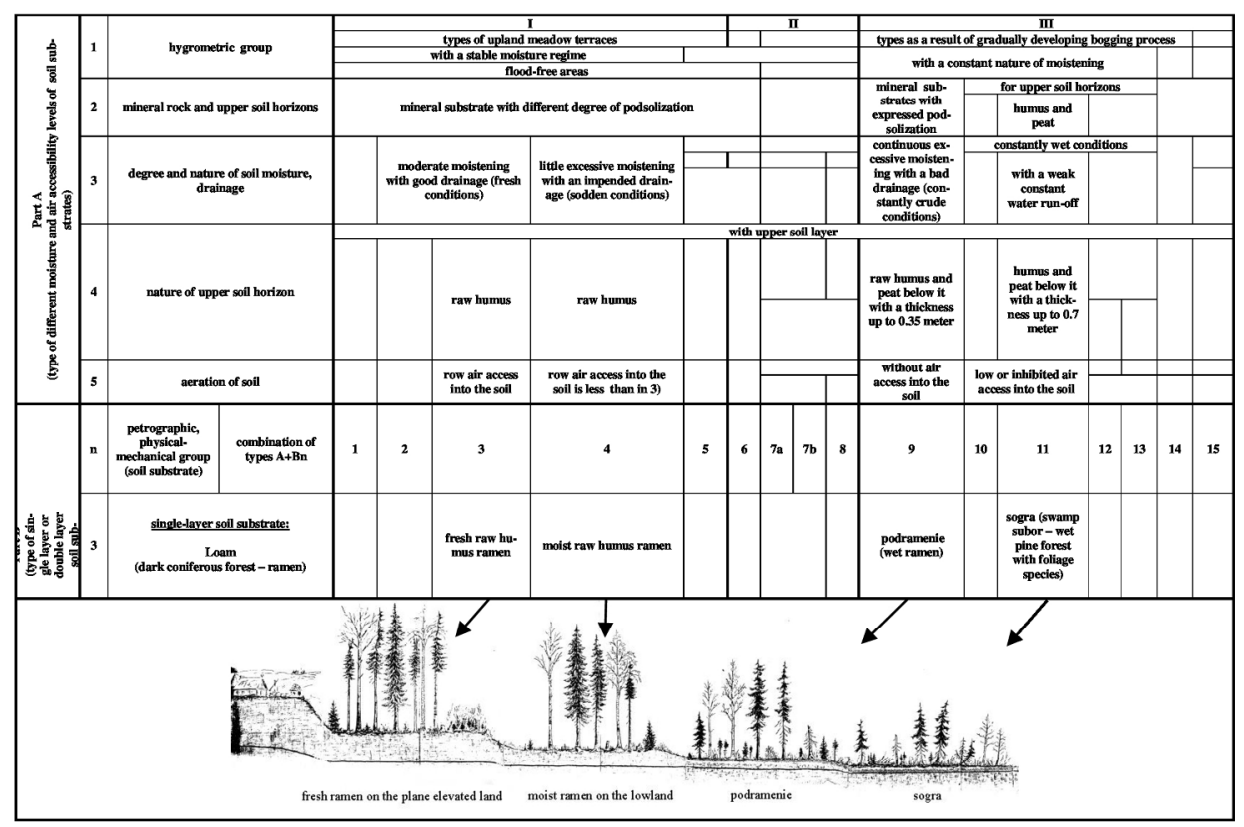

Fig. 2. The upper part of Krudener's (1916) classification table of types of habitat conditions and forest types, corresponding to the cells colored gray in Fig. 1. The schematic indicating the position of the forest types in the relief is shown at the bottom.

$297 \times 210 \mathrm{~mm}(200 \times 200 \mathrm{DPI})$ 


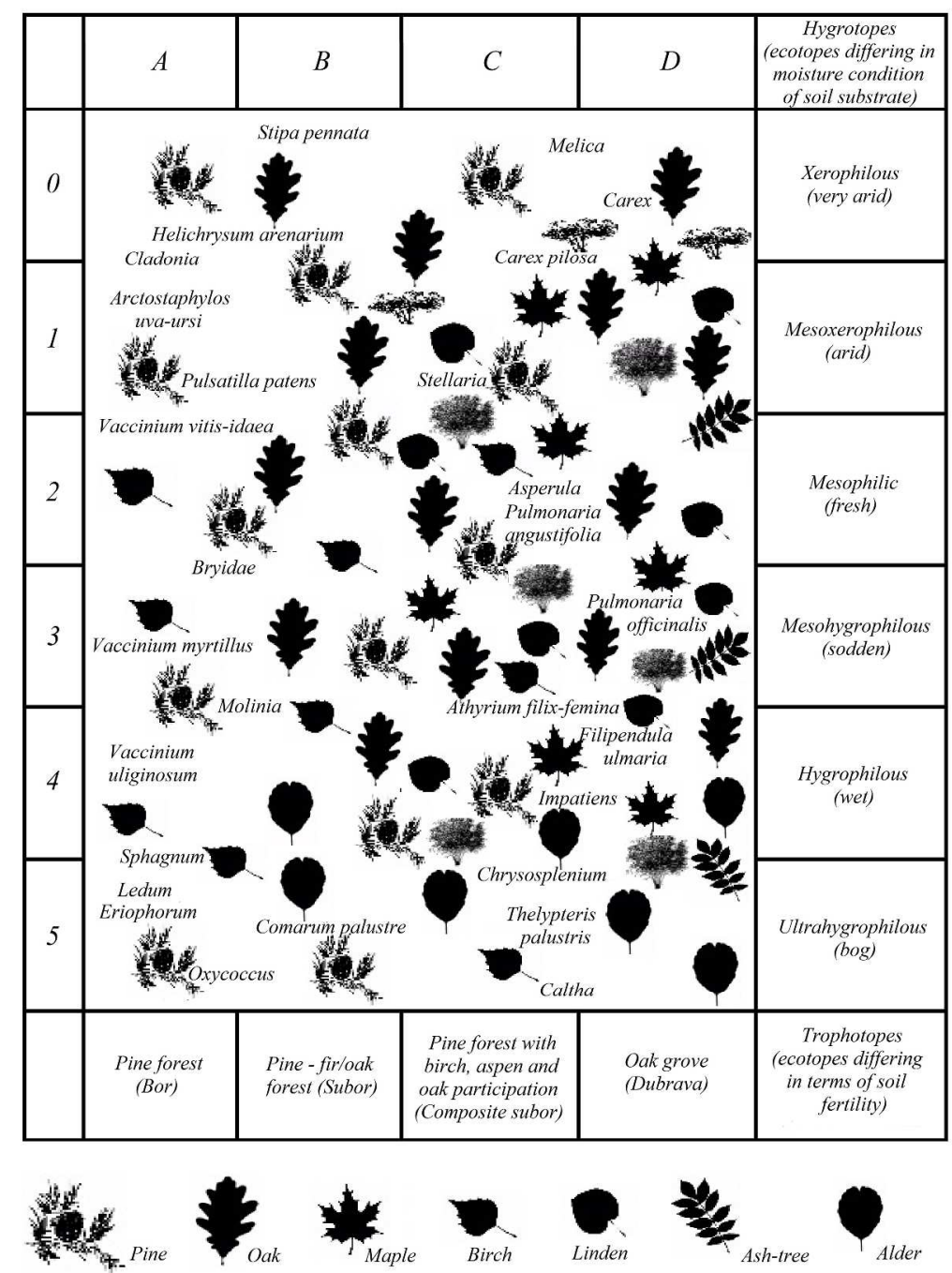

Fig. 3. Pogrebniyak's (1955) edaphic grid of types of habitat conditions and forest types: the range of trophic groups is plotted on the horizontal axis, and groups of soil moisture on the vertical axis.

$297 \times 420 \mathrm{~mm}(300 \times 300 \mathrm{DPI})$ 


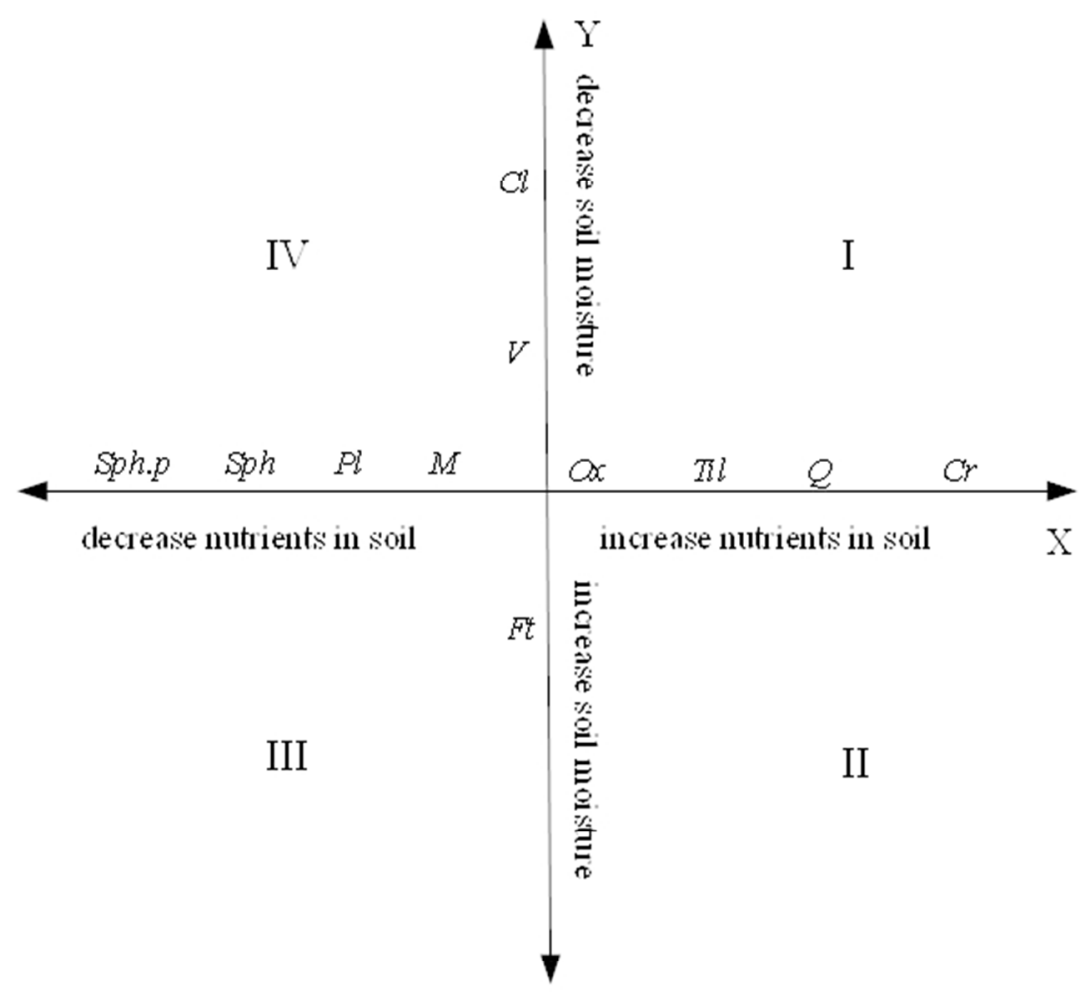

Fig. 4. The coordinate system of the generalized scheme of Sukachev's (1972) forest types classification. I loamy, well-drained soil. II - soil with excessive moisture from flowing water, an adequate supply of nutrients and oxygen, and a neutral or acidic reaction of soil solution. III - excessively wet, poorly drained soil with a small amount of nutrients, $\mathrm{pH}<7$. IV - well-drained dry soils, low in nutrients, with low acidity and sufficient aeration. Series of forest types: Ox - Oxalidosa, M - Myrtillosa, PI - Polytrichosa, Til - Tiliosa, Q - Quercetosa, Sph - Sphagnosa, V - Vacciniosa, Cl - Cladinosa, Ft - Fontinales, Sph.p - Sphagneta pinosa, $\mathrm{Cr}$ - Calcarela et Cretacea.

$253 \times 226 \mathrm{~mm}(72 \times 72 \mathrm{DPI})$ 
Comparison of features of main forest typologies in the Russian Federation

\begin{tabular}{|c|c|c|c|c|}
\hline \multirow[t]{2}{*}{ Feature } & \multicolumn{4}{|c|}{ Forest type classification and author(s) } \\
\hline & $\begin{array}{c}\text { Ecological or ecological-silvicultural } \\
\text { classification (E. V. Alekseev and } \\
\text { P. S. Pogrebniyak) }\end{array}$ & $\begin{array}{l}\text { Phytocoenotic } \\
\text { classification } \\
\text { (V. N. Sukachev) }\end{array}$ & $\begin{array}{l}\text { Genetic classification } \\
\text { (B. A. Ivashkevich and } \\
\text { B. P. Kolesnikov) }\end{array}$ & $\begin{array}{l}\text { Dynamic classification } \\
\text { (I. S. Melekhov) }\end{array}$ \\
\hline $\begin{array}{l}\text { Scope of the term } \\
\text { "forest type" }\end{array}$ & $\begin{array}{l}\text { Forest type is a set of forest areas } \\
\text { similar in soil, hydrological and } \\
\text { climatic conditions taking into account } \\
\text { the historical factor. It is defined } \\
\text { according to type of forest site } \\
\text { conditions (TFSC). Interpretations of } \\
\text { the scope of forest type have varied } \\
\text { over time: from the TFSC to the set of } \\
\text { forest biogeocenoses considered } \\
\text { within the type of forest site } \\
\text { conditions. In practice, this typology } \\
\text { has been widely adopted in regions } \\
\text { where the TFSC corresponds to a } \\
\text { certain type of forest stand; therefore, } \\
\text { to determine the forest type, it suffices } \\
\text { to determine the TFSC by means of an } \\
\text { edaphic grid. Only } 24 \text { types of forest } \\
\text { site conditions can be defined within } \\
\text { this grid. }\end{array}$ & $\begin{array}{l}\text { The type of forest is a } \\
\text { type of forest } \\
\text { biogeocenosis. There is } \\
\text { no limit on the number of } \\
\text { forest types that can be } \\
\text { identified. }\end{array}$ & $\begin{array}{l}\text { Forest type is a series of } \\
\text { closely related types of } \\
\text { forest phytocoenosis within } \\
\text { the type of forest site } \\
\text { conditions, i.e. a series of } \\
\text { types of forest } \\
\text { biogeocoenosis replacing } \\
\text { each other over time. The } \\
\text { scope of the term "forest } \\
\text { type" is broader than in } \\
\text { Sukachev's classification. } \\
\text { There is no limit on the } \\
\text { number of forest types that } \\
\text { can be identified. }\end{array}$ & $\begin{array}{l}\text { The scope of the term "forest } \\
\text { type" corresponds to } \\
\text { Sukachev's classification, } \\
\text { with the addition of the } \\
\text { stages of development of } \\
\text { forest vegetation: types of } \\
\text { felling and types of burnt } \\
\text { forest area. Possibility of one } \\
\text { forest type changing to } \\
\text { another also added. There } \\
\text { are no restrictions on the } \\
\text { number of forest types that } \\
\text { can be identified. }\end{array}$ \\
\hline Forest type boundary & $\begin{array}{l}\text { Along boundaries of type of forest site } \\
\text { conditions for forest-covered and } \\
\text { uncovered areas }\end{array}$ & $\begin{array}{l}\text { Along boundaries of } \\
\text { forest phytocoenosis only } \\
\text { for forest-covered areas, } \\
\text { taking into account the } \\
\text { type of forest site } \\
\text { conditions }\end{array}$ & $\begin{array}{l}\text { Along boundaries of forest } \\
\text { phytocoenosis only for } \\
\text { forest-covered areas, taking } \\
\text { into account the type of } \\
\text { forest site conditions }\end{array}$ & $\begin{array}{l}\text { Along boundaries of forest } \\
\text { phytocoenosis for forest- } \\
\text { covered and uncovered } \\
\text { areas, taking account of the } \\
\text { type of forest site conditions }\end{array}$ \\
\hline
\end{tabular}




\begin{tabular}{|c|c|c|c|c|}
\hline $\begin{array}{l}\text { Classification } \\
\text { features used to } \\
\text { determine the type of } \\
\text { forest site conditions }\end{array}$ & $\begin{array}{l}\text { Underlying rocks and soil (type, } \\
\text { mechanical composition, trophicity, } \\
\text { moisture) }\end{array}$ & $\begin{array}{l}\text { Direct factors (trophicity, } \\
\text { moistening and aeration } \\
\text { of soil) are estimated by } \\
\text { indirect indicators: } \\
\text { species of live ground } \\
\text { cover, position in relief } \\
\text { and hydrological regime }\end{array}$ & $\begin{array}{l}\text { Altitude (altitude class) for } \\
\text { mountain areas or regional } \\
\text { complex of forest growth } \\
\text { conditions for plain areas; } \\
\text { hydrological regime, } \\
\text { topography and soils. } \\
\text { Regionalization of territory } \\
\text { according to forest growth } \\
\text { conditions in genetic } \\
\text { classification is the strictest } \\
\text { and most elegant of the } \\
\text { typologies presented }\end{array}$ & $\begin{array}{l}\text { As in V. N. Sukachov's } \\
\text { classification }\end{array}$ \\
\hline $\begin{array}{l}\text { Classification } \\
\text { features of } \\
\text { phytocenosis used to } \\
\text { determine forest type }\end{array}$ & $\begin{array}{l}\text { Composition of the stand within the } \\
\text { forest site conditions, taking into } \\
\text { account the demand of plant species } \\
\text { for soil trophicity and soil moisture }\end{array}$ & $\begin{array}{l}\text { Composition of the tree } \\
\text { stand, indicators of living } \\
\text { ground cover, silvicultural } \\
\text { and taxation } \\
\text { characteristics, bonitet; } \\
\text { forest renewal }\end{array}$ & $\begin{array}{l}\text { Uses the classification } \\
\text { features of Sukachev's } \\
\text { typology for forest-covered } \\
\text { areas and the dominants of } \\
\text { the living ground cover for } \\
\text { non-covered sites by forest }\end{array}$ & $\begin{array}{l}\text { Uses the classification } \\
\text { features of Sukachev's } \\
\text { typology for forest-covered } \\
\text { areas and the dominants of } \\
\text { the living ground cover for } \\
\text { non-covered sites by forest }\end{array}$ \\
\hline $\begin{array}{l}\text { Account taken of } \\
\text { successional } \\
\text { dynamics }\end{array}$ & $\begin{array}{l}\text { Generally, at the level of theoretical } \\
\text { statements }\end{array}$ & $\begin{array}{l}\text { Generally, at the level of } \\
\text { theoretical statements }\end{array}$ & $\begin{array}{l}\text { Both at the level of } \\
\text { theoretical statements and in } \\
\text { classification schemes for } \\
\text { practical use in forest } \\
\text { inventory and forest } \\
\text { management. Age and } \\
\text { recovery succession are } \\
\text { presented in the form of a } \\
\text { series of possible types of } \\
\text { phytocoenosis, replacing } \\
\text { each other in time, within } \\
\text { the specific type of forest } \\
\text { site conditions. }\end{array}$ & $\begin{array}{l}\text { Typologies of felling and } \\
\text { burnt areas as stage of } \\
\text { recovery dynamics } \\
\text { preceding the formation of a } \\
\text { forest type are developed. } \\
\text { Transition from one forest } \\
\text { type to another for forest- } \\
\text { covered areas is provided for } \\
\text { at the level of theoretical } \\
\text { propositions }\end{array}$ \\
\hline $\begin{array}{l}\text { Account taken of } \\
\text { impact of }\end{array}$ & $\begin{array}{l}\text { At the level of theoretical statements } \\
\text { for direct anthropogenic impacts; }\end{array}$ & $\begin{array}{l}\text { At the level of theoretical } \\
\text { statements for direct }\end{array}$ & $\begin{array}{l}\text { Both at the level of } \\
\text { theoretical statements, and in }\end{array}$ & $\begin{array}{l}\text { Both at the level of } \\
\text { theoretical statements and }\end{array}$ \\
\hline
\end{tabular}




\begin{tabular}{|l|l|l|l|l|} 
anthropogenic factors & $\begin{array}{l}\text { indirect impacts are not taken into } \\
\text { account }\end{array}$ & $\begin{array}{l}\text { anthropogenic impacts; } \\
\text { indirect impacts are not } \\
\text { taken into account }\end{array}$ & $\begin{array}{l}\text { the classification schemes } \\
\text { for types of cutting (with or } \\
\text { without burning wood } \\
\text { residues) developed for use } \\
\text { in forest inventory and forest } \\
\text { management; indirect } \\
\text { impacts are not taken into } \\
\text { account }\end{array}$ & $\begin{array}{l}\text { for practical use } \\
\text { felling and burnt areas); } \\
\text { indirect impacts are not } \\
\text { taken into account }\end{array}$ \\
\hline $\begin{array}{l}\text { Level of } \\
\text { implementation in } \\
\text { forest inventory and } \\
\text { forest management } \\
\text { practice; regions of } \\
\text { implementation in the } \\
\text { Russian Federation }\end{array}$ & $\begin{array}{l}\text { Moderate (some southern regions of } \\
\text { the Russian Federation) }\end{array}$ & $\begin{array}{l}\text { Very high (European part } \\
\text { of the Russian Federation; } \\
\text { regions of Western and } \\
\text { Eastern Siberia) }\end{array}$ & $\begin{array}{l}\text { High (Far East, Urals, some } \\
\text { regions of the European part } \\
\text { of the Russian Federation, } \\
\text { some regions of Western } \\
\text { Siberia) }\end{array}$ & $\begin{array}{l}\text { Limited use as a supplement } \\
\text { to V. Sukachev's } \\
\text { classification }\end{array}$ \\
\hline
\end{tabular}

